\title{
OBITUARIES
}

\section{Dr. Oliver E. Buckley}

Dr. Oliver E. Buckley died on December 14. $\mathrm{He}$ will be remembered for many things in the science and technology of electricity. His early years were notable for researches on such diverse topics as the Hall effect, ionization manometers, magnetic materials and submarine cables. His later years were occupied with important government advisory committees and boards. In between came an outstanding but quietly accomplished achievement that will increase in stature as the years go by. This was his work in assuring that basic research will have a secure place in the industrial laboratories of the future. It was he who took over from Dr. F. B. Jewett, the first president of the Bell Telephone Laboratories, a group of scientists who had already given promise of what basic research could do for an industry. Dr. Buckley saw and appreciated this promise. It was he who protected this group from pressures to digress into development. It was he who made it into a recognized function of the Laboratories' activities. It was he who turned it over in mature form to his successor, Dr. Mervin J. Kelly, when he retired from the presidency of the Laboratories in 1951 and as chairman of the Board in 1952.

Dr. Buckley was born in Sloan, Iowa, in 1887. He received the B.S. degree from Grinnell College in 1909 and the Ph.D. from Cornell University in 1914. $\mathrm{He}$ immediately joined the Western Electric Company as a research physicist. He soon developed an ionization manometer which was an important tool in the early work on vacuum tubes. Taking an interest in new magnetic materials, he was quick to recognize possibilities in the use of permalloy to increase the speed of telegraph transmission on submarine cable. When perminvar came along, he envisaged a submarine cable capable of transmitting human speech. This project was carried far enough to show that it was quite practical from a technical point of view. The economics of the times determined its fate. Dr. Buckley's interest never flagged, however. In 1932 he started a group working on a multichannel system employing repeaters powered at relatively low voltage with current sent through the cable itself. While this project was never completed in the original form, the work done on it was basic to the cables that now are in operation carrying many conversations across the Atlantic, to Alaska, to Hawaii and soon across the entire Pacific.

When the Western Electric Company's engineering department became Bell Telephone Laboratories in 1925, he was appointed assistant director of research. In 1933 he became director of research and in 1936 executive vice-president. He served as president from 1940 until 1951 and as chairman of the Board until he retired in 1952. During this time many technical advances were made. These included the wave-guide, the transistor, information theory and applications including plastic cable sheaths, automatic message accounting, nation-wide dialing, and micro-wave relay networks.

In the course of his career, Dr. Buckley received many honours and served on a number of important committees. He was a member of the General Advisory Committee of the Atomic Energy Com- mission, 1948-54, was appointed by the President to be the first chairman of the Science Advisory Committee, and was a member of the National Inventors' Council. He received the Medal for Merit, the nation's highest civilian award, in recognition of his contribution during the Second World War. He was a Fellow of the American Physical Society, the American Association for the Advancement of Science, the Acoustical Society of America, the American Academy of Arts and Sciences, and the American Institute of Electrical Engineers, of which he was vice-president during 1946-48. He was a member of the U.S. National Academy of Sciences, the New York Academy of Sciences, the Franklin Institute, and the American Philosophical Society, of which he served as vice-president in 1954-55.

In the face of these and other achievements, honours and activities, Dr. Buckley retained his characteristic friendly enthusiasm and love for people. He knew a great many of them, and knew how to work with them. To-day, more and more, we see industrial laboratories engaged in basic research. A large share in promoting this belongs to Dr. Buckley. By example in his own laboratories, by logic and inspiring discussion on boards and in committeo meetings, and by personal contacts he made people see the need for this type of research and the harvests to be reaped from its cultivation. He has sowed well. The reaping will increase with the years.

\section{F. B. TlLeweliy}

\section{Captain Guy Gardner}

HaD he lived a little longer, Captain Guy Gardner's name would have been better known to archæologists in Great Britain than can be the case before the important record, in book form, of his prolonged excavations at the great proto-historic site of Mapungubwe in the Transvaal is available. His death in Johannesburg on Christmas Eve, aged seventy-eight. emphasizes the evils of over-delay in publication, in this case beyond the author's control. For the work was done in six consecutive seasons between 1935 and 1940, and written up during and after the ensuing war years. Its speedy publication is surely now a duty imposed on academic bodies in the Union of South Africa with or without a Government subvention.

Gardner was not a professional archæologist, and, indeed, had his first taste of field-work with me in the Faiyum in 1927-28. But though farming in Natal had been his livelihood ever since he settled in South Africa as a young man, he had loved history and archæology, particularly classical, all his life ; and in the Graeco-Roman remains of my Faiyum concession he rejoiced in his introduction to the reality of the beloved. "The Desert Fayum", Chapter 31, contains his unaided report, illustrated by plans and by drawings of pottery which at the time were the first substantial groups known securely dated to the reign of Ptolemy II.

A more ambitious opportunity followed. The now famous kopje site of Mapungubwe Hill, accidentally discovered in 1932, had been partially dug by the late Neville Jones and J. F. Schofield in 1934; it had disclosed an iron-age Bantu culture, rich in gold 